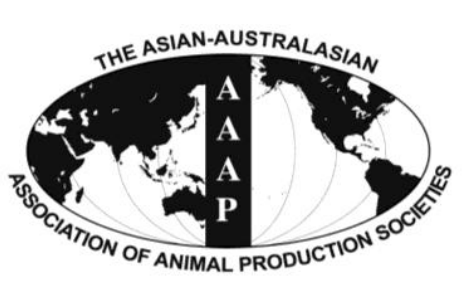

Open Access

Asian Australas. J. Anim. Sci.

Vol. 28, No. 8 : 1171-1177 August 2015

http://dx.doi.org/10.5713/ajas.14.0848

www.ajas.info

pISSN 1011-2367 elSSN 1976-5517

\title{
Isolation, Culture and Identification of Porcine Skeletal Muscle Satellite Cells
}

\author{
Bo-jiang Li ${ }^{1, a}$, Ping-hua $\mathrm{Li}^{1,2, a}$, Rui-hua Huang ${ }^{1,2}$, Wen-xing $\operatorname{Sun}^{1}$, Han Wang ${ }^{1}$, Qi-fa Li $^{1}$, \\ Jie Chen ${ }^{1}$, Wang-jun $\mathrm{Wu}^{1,2, *}$, and Hong-lin Liu ${ }^{1, *}$ \\ ${ }^{1}$ Department of Animal Genetics, Breeding and Reproduction, College of Animal Science and Technology, \\ Nanjing Agricultural University, Nanjing 210095, China
}

\begin{abstract}
The objective of this study was to establish the optimum protocol for the isolation and culture of porcine muscle satellite cells. Mononuclear muscle satellite cells are a kind of adult stem cell, which is located between the basal lamina and sarcolemma of muscle fibers and is the primary source of myogenic precursor cells in postnatal muscle. Muscle satellite cells are a useful model to investigate the mechanisms of muscle growth and development. Although the isolation and culture protocols of muscle satellite cells in some species (e.g. mouse) have been established successfully, the culture system for porcine muscle satellite cells is very limited. In this study, we optimized the isolation procedure of porcine muscle satellite cells and elaborated the isolation and culture process in detail. Furthermore, we characterized the porcine muscle satellite cells using the immunofluorecence. Our study provides a reference for the isolation of porcine muscle satellite cells and will be useful for studying the molecular mechanisms in these cells. (Key Words: Pig, Skeletal Muscle Satellite Cell, Isolation, Culture, Characterization)
\end{abstract}

\section{INTRODUCTION}

In livestock animals, skeletal muscle is the main component of lean body mass and its growth is the major factor affecting body growth. Generally, the number of muscle fibers is fixed in the prenatal stage, thus postnatal skeletal muscle growth is mainly caused by hypertrophy of existing muscle fibers. Skeletal muscle satellite cells, a kind of adult stem cell, are located between the basal lamina and sarcolemma of the muscle fibers, and have proven to be responsible for skeletal muscle hypertrophy and regeneration (Rhoads et al., 2009). Myogenic satellite cells

\footnotetext{
* Corresponding Authors: Wang-jun Wu. Tel: +86-25-84399762, Fax: +86-25-84399762, E-mail: wuwangjun2009@ hotmail.com / Hong-lin Liu. Tel: +86-25-84395106, Fax: +86-25-84395106, E-mail: liuhonglin@njau.edu.cn

${ }^{2}$ Huaian Academy of Nanjing Agricultural University, Huaian, Jiangsu, 223001, China.

a These authors contributed equally to this work as co-first authors.

Submitted Nov. 1, 2014; Revised Jan. 12, 2015; Accepted Feb. 22, 2015
}

were first discovered in the frog (Mauro, 1961), followed by numerous distinct methods developed to isolate the muscle satellite cells from different species, e.g. rat (Rosenblatt et al., 1995), human (Blau and Webster, 1981), chicken (Bennett et al., 1986), ovine (Dodson et al., 1986), bovine (Dodson et al., 1987). Porcine skeletal muscle satellite cells were first isolated and cultured in 1992 (Doumit and Merkel, 1992). Afterwards, porcine skeletal muscle satellite cells were isolated using similar or improved methods and were used to investigate the mechanisms of skeletal muscle growth and development (Mesires and Doumit, 2002; Theil et al., 2006; Mau et al., 2008; Wilschut et al., 2010). However, detailed isolation procedures for porcine skeletal muscle satellite cells were not described in these studies, and these methods were time-consuming due to cumbersome steps and produced a low number of satellite cells, which limited the studies on muscle growth and development in pigs. In this study, the isolating processes for porcine skeletal muscle satellite cells were optimized and elaborated in detail, and the characterization of the isolated porcine skeletal muscle 
satellite cells was further validated. Our study provides a technique for isolation of porcine skeletal muscle satellite cells and will provide material for studying the molecular mechanisms in porcine muscle satellite cells.

\section{MATERIALS AND METHODS}

\section{Reagents}

Before starting the isolation of porcine muscle satellite cells, the following reagents need to be purchased, including Dulbecco's Modified Eagle Medium, high glucose (DMEM-HG) (Invitrogen, Grand Island, USA. cat. no. 11995-065), fetal bovine serum (FBS) (Invitrogen, Carlshad, CA, USA. cat. no. 12664-025), horse serum (HS) (Invitrogen, New Zealand, cat. no. 26050-070), 2-[4-(2hydroxyethyl)-1-piperazine]-1-ethanesulfonic acid buffer (HEPES buffer, $1 \mathrm{M}$ ) (Life Technologies, Grand Island, NY, USA. cat. no. 15630106), Phosphate-buffered saline (PBS) (Life Technologies, Grand Island, NY, USA. cat. no. 10010023), $0.25 \%$ Trypsin-ethylenediaminetetraacetic acid (Life Technologies, NY, Grand Island, USA. cat. no. 25200056), Protease from Streptomyces griseus (Sigma, St. Louis, MO, USA. cat. no. P8811, $3.5 \mathrm{U} / \mathrm{mg}$ ); Collagenase from Clostridium histolyticum (Sigma, St. Louis, MO, USA. cat. no. C7657), $100 \times$ Penicillin-Streptomycin $(10,000 \mathrm{U} / \mathrm{mL})$ (Invitrogen, Carlsbad, CA, USA. cat. no. 15140-122) and $100 \%$ ethanol (GB 678-2002, Beijing, China).

\section{Reagents preparation}

Subsequently, the cell culture reagents need to be prepared carefully. The 100xpenicillin-streptomycin solution was diluted to 1 fold with PBS to prepare the 1×penicillin-streptomycin PBS (+), and the final concentration of penicillin and streptomycin was $100 \mathrm{U} / \mathrm{mL}$ and $100 \mu \mathrm{g} / \mathrm{mL}$, respectively. The PBS (+) was stored at $4{ }^{\circ} \mathrm{C}$ until using. The $20 \%$ FBS proliferation medium (PM) was prepared with DMEM-HG and FBS according to the ratio of 4:1, e.g. $100 \mathrm{~mL} \mathrm{20 \%} \mathrm{FBS} \mathrm{PM} \mathrm{was} \mathrm{prepared} \mathrm{with}$ $80 \mathrm{~mL}$ DMEM-HG and $20 \mathrm{~mL}$ FBS. The PM was stored at $4^{\circ} \mathrm{C}$ until using or prepared freshly. The 100xpenicillinstreptomycin solution was diluted to 1 fold with PM to prepare 20\% FBS proliferation medium+ $(\mathrm{PM}+)$, the final concentration of penicillin and streptomycin was $100 \mathrm{U} / \mathrm{mL}$ and $100 \mu \mathrm{g} / \mathrm{mL}$, respectively. The PM+ was stored at $4^{\circ} \mathrm{C}$ until using (not too long before using) or prepared before using. The $2 \%$ HS differentiation medium (DM) was prepared with DMEM-HG and HS according to the ratio of $50: 1$, and the DM was stored at $4^{\circ} \mathrm{C}$ until using (not too long before using). $1.5 \mathrm{mg}$ proteases $(3.5 \mathrm{U} / \mathrm{mg}$ ) was added to $1 \mathrm{~mL}$ preheated PBS including $1.0 \% \operatorname{HEPES}\left(37^{\circ} \mathrm{C}\right)$ to prepare $1.5 \mathrm{mg} / \mathrm{mL}$ proteases from streptomyces griseus solution, the solution was gently mixed and filtered through
$0.22 \mu \mathrm{m}$ filter, and stored at $-20^{\circ} \mathrm{C}$. The collagenase type XI of $1.5 \mathrm{mg}$ was added to $1 \mathrm{~mL}$ preheated DMEM-HG containing $5 \%$ FBS $\left(37^{\circ} \mathrm{C}\right)$ to prepare $1.5 \mathrm{mg} / \mathrm{mL}$ collagenase type XI from clostridium histolyticum solution containing 5\% FBS, the solution was filtered through 0.22 $\mu \mathrm{m}$ filter, and stored at $-20^{\circ} \mathrm{C}$. The freezing medium was prepared with dimethyl sulfoxide (DMSO) and FBS according to the ratio of $1: 5$, e.g. $1 \mathrm{~mL}$ freezing medium was prepared with $200 \mu \mathrm{L}$ DMSO and $800 \mu \mathrm{L}$ FBS, and then gently mixed. The freezing medium was prepared before using. The ethanol of $75 \%$ and $70 \%$ was prepared with $100 \%$ ethanol and sterilized ultrapure water according to the ratio $3: 1$ and 7:3, respectively. E.g. $100 \mathrm{~mL} 75 \%$ ethanol was prepared with $75 \mathrm{~mL} 100 \%$ ethanol and $25 \mathrm{~mL}$ sterilized ultrapure water, and the solution was gently mixed.

\section{Instruments and consumables}

The following instruments, including water bath, centrifuge, incubator, light microscope, confocal microscopy, ice maker, are required for the isolation of porcine muscle satellite cells. In addition, the following consumables also need to be prepared, including scalpels, razor blades, forceps, scissors, cell strainers (pore size 40 $\mu \mathrm{m}, 70 \mu \mathrm{m}, 100 \mu \mathrm{m}$ ), plastic petri dishes, polypropylene centrifuge tubes $(15 \mathrm{~mL}, 50 \mathrm{~mL})$, culture flask (T75, T25), Cryo tube vials, 6-wells culture dishes. All the consumables must be sterile and then can be directly used for cell culture.

\section{Pig muscle tissues collection}

The DurocxYorkshirexLandrace newborn piglets less than one week old were provided by Jiangpu Farm of Nanjing Agricultural University. The piglets were slaughtered at College of Animal Science and Technology of Nanjing Agricultural University according to the Animal Care and Use Statute of China, and all the sample collections were specifically approved by the ethics committee of Nanjing Agricultural University.

After slaughter, the body surface of the piglets was sterilized with $75 \%$ ethanol, and then transferred in to the cell culture laboratory for muscle tissue collection. The hair on hind legs was removed and the skin of the hind legs sterilized with $75 \%$ ethanol, then the whole semitendinosus (ST) and semimembranosus (SM) muscles on the right and left were dissected using scalpels, respectively.

\section{Isolation and culture procedures of muscle satellite cells}

Firstly, the collected muscles were quickly sterilized with $70 \%$ ethanol in a plastic petri dish, and then immediately transferred into a new plastic petri dish with cold PBS (+) and rinsed 3 to 4 times with 4 fold volume cold PBS (+) in a new plastic petri dish. Visible adipose and connective tissues on the muscle mass were removed with a 
scalpel in laminar-flow hoods or Biological safety cabinets.

Secondly, the whole ST or SM muscles were excised and cut into small pieces using scissors under the cold PBS (+) containing $1 \%$ HEPEs in a plastic petri dish and the shredded muscle pieces were transferred into $15 \mathrm{~mL}$ polypropylene centrifuge tubes, centrifuged at $1,000 \mathrm{~g}$ for 5 min to separate the supernatant and shredded muscle pellet. The supernatant was again centrifuged at 2,000 $\mathrm{g}$ for $5 \mathrm{~min}$ to collect a second pellet. Then 2 to 4 folds volume 1.5 $\mathrm{mg} / \mathrm{mL}$ Protease solution was added to the pooled collected pellets (ensuring the muscle pieces were covered by protease solution).

Thirdly, the $15 \mathrm{~mL}$ polypropylene centrifuge tubes containing the muscle pieces were digested in a water bath at $37^{\circ} \mathrm{C}$ for $1 \mathrm{~h}$ with $10 \mathrm{~min}$ shaking (a continuous shaking water bath would be better) and the digested muscle pieces were aspirated back and forth for 10 to 15 times with 5 or $25 \mathrm{~mL}$ pipettes to gently dissociate the cells, and centrifuged for $5 \mathrm{~min}$ at $200 \mathrm{~g}$ to separate the supernatant containing the cell pellet and the underlying tissue fragments pellet. While the underlying tissue fragment pellets were temporarily kept on ice for subsequent collagenase type XI digestion. Then, the supernatant was transferred into $15 \mathrm{~mL}$ polypropylene centrifuge tubes and was centrifuged for $5 \mathrm{~min}$ at 2,000 $\mathrm{g}$ to collect the cell pellet, and the cell pellet was further resuspended with $10 \mathrm{~mL}$ $\mathrm{PM}+$, and then centrifuged for $10 \mathrm{~min}$ at 2,000 $\mathrm{g}$ to collect the cell pellet again. Afterwards, the cell pellet was resuspended again with $5 \mathrm{~mL} \mathrm{PM}+$, and the cell suspension was filtered through $100 \mu \mathrm{m}$ and $70 \mu \mathrm{m}$ cell strainers, successively. Then, the filtered cell suspension was centrifuged for $10 \mathrm{~min}$ at $2,000 \mathrm{~g}$ to collect the cell pellet (Pellet I), and the cell pellet was resuspended with $1 \mathrm{~mL}$ $\mathrm{PM}+$ again and kept on ice.

Fourthly, the underlying tissue fragment pellet derived from the third step was further digested for $1 \mathrm{~h}$ with 2 to 4 folds pre-prepared collagenase type XI solution. Similarly, the tissue fragments were aspirated for 10 to 15 times with 5 or $25 \mathrm{~mL}$ pipettes to gently dissociate the cells and filtered through a $100 \mu \mathrm{m}$ cell strainer, Then, the filtrated cell suspension was centrifuged for $5 \mathrm{~min}$ at 2,000 $\mathrm{g}$ to separate the supernatant and the cell pellet, and the supernatant centrifuged for $10 \mathrm{~min}$ at $2,000 \mathrm{~g}$ to collect the residual cell pellet, and both collected cell pellets were mixed. Next, the cell pellet was resuspended with $10 \mathrm{~mL} \mathrm{PM}+$ in $15 \mathrm{~mL}$ polypropylene centrifuge tubes and the cell suspension was filtered through a $70 \mu \mathrm{m}$ cell strainer, and then centrifuged for $5 \mathrm{~min}$ at 2,000 $\mathrm{g}$ to collect the cell pellet (Pellet II). The cell pellet was resuspended with $1 \mathrm{ml} \mathrm{PM+} \mathrm{and} \mathrm{kept} \mathrm{on} \mathrm{ice.}$

Fifthly, the cell suspension (Pellet I and Pellet II) were mixed in $15 \mathrm{~mL}$ polypropylene centrifuge tubes and centrifuged for $5 \mathrm{~min}$ at 2,000 $\mathrm{g}$ to recover the Pellet $\mathrm{I}$ and
Pellet II. Next, the cell pellet was resuspended with $10 \mathrm{~mL}$ cold PBS (+) and centrifuged for $10 \mathrm{~min}$ at 2,000 $\mathrm{g}$ to collect the cell pellet. Subsequently, the cell pellet was resuspended with $5 \mathrm{~mL} \mathrm{PM}+$ again and the cell suspension was filtered through a $40 \mu \mathrm{m}$ cell strainer. Then, the cell suspension was adjusted to $10 \mathrm{~mL}$ with $\mathrm{PM}+$, centrifuged for $10 \mathrm{~min}$ at $700 \mathrm{~g}$ to collect the cell pellet.

Finally, the cell pellet was resuspended in $10 \mathrm{~mL} 37^{\circ} \mathrm{C}$ preheated $\mathrm{PM}+$ and the cell suspension was pre-plated in T75 cell culture flask and incubated at $37^{\circ} \mathrm{C}$ under $5 \% \mathrm{CO}_{2}$ for $1 \mathrm{~h}$. The fibroblasts become quickly adherent to the bottom of cell culture flask, while the skeletal muscle satellite cells will remain in the supernatant. Then, the supernatant containing the skeletal muscle satellite cells was collected to $15 \mathrm{~mL}$ polypropylene centrifuge tube and centrifuged for $10 \mathrm{~min}$ at $500 \mathrm{~g}$, and the cell pellet was resuspended with $10 \mathrm{~mL} \mathrm{PBS}+$, centrifuged for $10 \mathrm{~min}$ at $500 \mathrm{~g}$ to collect the skeletal muscle satellite cells pellet. Afterwards, the skeletal muscle satellite cells pellet was resuspeneded with $10 \mathrm{~mL} 37^{\circ} \mathrm{C}$ preheated $\mathrm{PM}+$ and plated in $\mathrm{T} 75$ cell culture flask and incubated at $37^{\circ} \mathrm{C}$ under $5 \%$ $\mathrm{CO}_{2}$.

\section{Identification of muscle satellite cells}

To characterize the porcine skeletal muscle satellite cells, the isolated cells were plated into covered 6-well plates at a density of $10^{5}$ cells $/ \mathrm{mL}$ per well and cultured in an incubator at $37^{\circ} \mathrm{C}$ with $5 \% \mathrm{CO}_{2}$ until to $70 \%$ to $80 \%$ confluent. Subsequently, immunofluorescence staining with specific antibodies was performed to identify the porcine skeletal muscle satellite cells. Briefly, the cells were washed three times with PBS and fixed with $4 \%$ paraformaldehyde for $30 \mathrm{~min}$ at room temperature, and then washed three times for $5 \mathrm{~min}$ each with PBS again, followed by permeabilization with $0.5 \%$ Triton $\mathrm{X}-100$ for $30 \mathrm{~min}$ at room temperature. Afterward, the cells were blocked with $1 \%$ bovine serum albumin (BSA)-supplemented PBS for 1 $\mathrm{h}$ and incubated overnight at $4^{\circ} \mathrm{C}$ or $4 \mathrm{~h}$ at room temperature with anti-Pax7 primary antibody (Santa Cruz Tech, Santa Cruz, CA, USA) and anti-Desmin primary antibody (Santa Cruz Tech, USA). After three washes for $5 \mathrm{~min}$ each time in PBS, the cells were labeled with appropriate fluoresceinlabeled secondary antibody for $1 \mathrm{~h}$ in the dark at room temperature, and followed by washing three times in PBS again (5 min each time). Meanwhile, the cell nuclei were counterstained with 4', 6-diamidino-2-phenylindole for 5 min, and then the samples were mounted on glass slides and examined on confocal laser scanning microscope (Zeiss LSM 700 META, Jena, Germany).

\section{Proliferative properties of muscle satellite cells}

Proliferative properties of the porcine skeletal muscle 
satellite cells were detected using cell counting kit-8 (CCK8) (Dojindo, Tokyo, Japan). The isolated cells were seeded into 96-well plates at a density of $2 \times 10^{3}$ cells/well with 100 $\mu \mathrm{L}$ culture medium. After $1,2,3,4,5,6$, and $7 \mathrm{~d}$ of incubation at $37^{\circ} \mathrm{C}$ with $5 \% \mathrm{CO}_{2}$, respectively, $10 \mu \mathrm{L} \mathrm{CCK}$ 8 solution was added to each well and incubated in $5 \% \mathrm{CO}_{2}$ at $37^{\circ} \mathrm{C}$ for $4 \mathrm{~h}$. Finally, absorbance was measured at 450 nm using a Multiskan GO Microplate Spectrophotometer (Thermo Scientific, Waltham, MA, USA). All tests were carried out in ten replicates and the data were presented as means \pm standard error. All statistical analyses were performed using SPSS version 18.0. Differences between two adjacent groups were evaluated using unpaired-sample $t$-test. A $\mathrm{p}$ value $<0.05$ is shown as $*, \mathrm{p}<0.01$ is shown as $* *$, and $\mathrm{p}<0.001$ is shown as $* * *$.

\section{Differentiation characteristics of muscle satellite cells}

To validate the differentiation characteristics of skeletal muscle satellite cells, the isolated cells were seeded into the 6 -well plates at a density of $10^{4}$ cells $/ \mathrm{mL}$ per well and were cultured with DMEM supplemented with $10 \%$ FBS in an incubator at $37^{\circ} \mathrm{C}$ with $5 \% \mathrm{CO}_{2}$ until $50 \%$ confluent. Then, the cells were cultured with DMEM containing $2 \%$ HS to induce differentiation and the cell morphology was observed with an inverted microscope (Leica fluorescence microscope, Mannheim, Germany). Moreover, the differentiation characteristics of muscle satellite cells were confirmed with differentiation biomarker protein antimyogenin (Santa Cruz, USA) using immunofluorescence staining. The protocol was performed according to the method mentioned above.

\section{RESULTS AND DISCUSSION}

Skeletal muscle satellite cells are a useful model to investigate the mechanisms of muscle growth and development. Pigs are one of the most important economic animals and make a substantial contribution towards meeting human nutritional requirements. Therefore, the study of porcine skeletal muscle growth and development using the porcine skeletal muscle satellite cell model is of great importance.

The earliest skeletal muscle satellite was found in an electron microscopic study of the peripheral region of the frog skeletal muscle fiber (Mauro, 1961), but the first viable satellite cells were isolated from adult rat skeletal muscles (Bischoff, 1974). Afterward skeletal muscle satellite cells from different species were isolated according to the protocol established by Bischoff in 1974, while the isolation and culture of porcine skeletal muscle satellite commenced in 1992 (Doumit and Merkel, 1992). Although the isolating and culturing protocols for skeletal muscle satellite cells were established in many species, the processing conditions may differ considerably between species. Furthermore, methods have been updated continuously with the developments inbiotechnology. Therefore, updates of these methods will accelerate the research progress of skeletal muscle growth and development using satellite cells model. At present, two major approaches have been applied to isolate skeletal muscle satellite cells, the first approach is to break down the connective tissue network and myofibers to release the muscle satellite cells based on the mincing, enzymatic digestion and repetitive trituration of the muscle mass. This is the classical and efficient method to obtain enough muscle satellite cells, although this method may obtain a heterogeneous population of precursor cells. The second approach is to isolate the muscle satellite cells from single intact muscle fiber, which can obtain relatively pure muscle satellite cells, and this method has been successfully used in studies of muscle satellite cells in rats (Kastner et al., 2000), mice (Shefer and Yablonka-Reuveni, 2005) and humans (Bonavaud et al., 2002). In the present study, the approach was based on enzymatic digestion to isolate the porcine skeletal muscle satellite cells. In the isolating process, proteases from Streptomyces griseus and collagenase type XI were chosen to digest the skeletal muscle tissues. The concentration and digestion time were optimized to achieve the satisfactory dissociation and viability cells according to the characteristics of muscle tissues and the product manual.

Skeletal muscle satellite cells are a kind of adult stem cells, therefore postnatal stages were suitable for the isolation of skeletal muscle satellite cells. The previous studies indicated that the absolute number increased between 1 and 32 weeks of age. This number was at least maintained between 1 and 64 weeks of age; however, the relative proportion of porcine skeletal muscle satellite cells gradually decreased from 1 to 64 weeks after birth (Campion et al., 1981; Mesires and Doumit, 2002). Therefore it is better to select newborn piglets at no more than two weeks of age to obtain a high proportion of muscle satellite cells. In this study, one week old piglets were used to isolate the skeletal muscle satellite cells and good positive skeletal muscle satellite cells were obtained.

Skeletal muscle satellite cells are located between the basal lamina and sarcolemma of the muscle fibers. While the number of muscle satellite cells may differ considerably among specific skeletal muscles in different parts of body, e.g. the extensor digitorum longus (EDL) and the soleus (SOL) muscle in mouse, the number of satellite cells in SOL is greater than in EDL from 2 to 3 months old mice (Di Foggia and Robson, 2012). Notably, the hindlimb muscles are generally used to isolate the skeletal muscle satellite. For example, the SM and ST muscles are mostly 
A

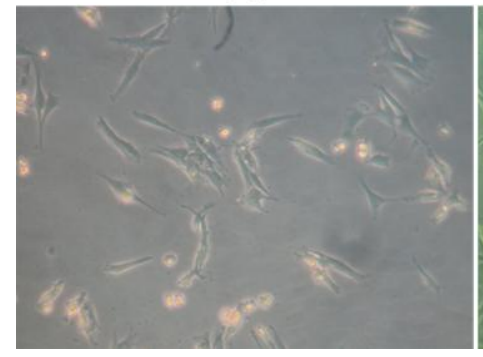

B

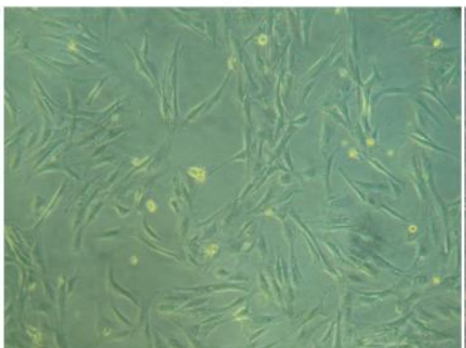

C

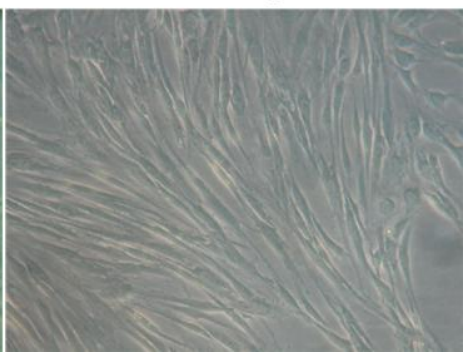

Figure 1. Morphological characteristics of isolated porcine skeletal muscle satellite cells under microscope with white light $(\times 100)$. (A) Proliferating muscle satellite cells at low density stage. (B) Proliferating muscle satellite cells at high density stage. (C) Differentiated myotubules from muscle satellite cells.

used for the isolation of skeletal muscle satellite cells in to isolate the skeletal muscle satellite cells from mice pigs (Doumit and Merkel, 1992; Blanton et al., 1999; (Shefer and Yablonka-Reuveni, 2005). In the present study, Mesires and Doumit, 2002; Mau, Oksbjerg et al., 2008; porcine SM, ST and longissimus dorsi muscles were chosen Wilschut et al., 2008), while the limb muscles extensor to isolate muscle satellite cells. Our results indicate that the EDL, tibialis anterior, and flexor digitorum brevis are used muscle satellite cells can be isolated from three kinds of

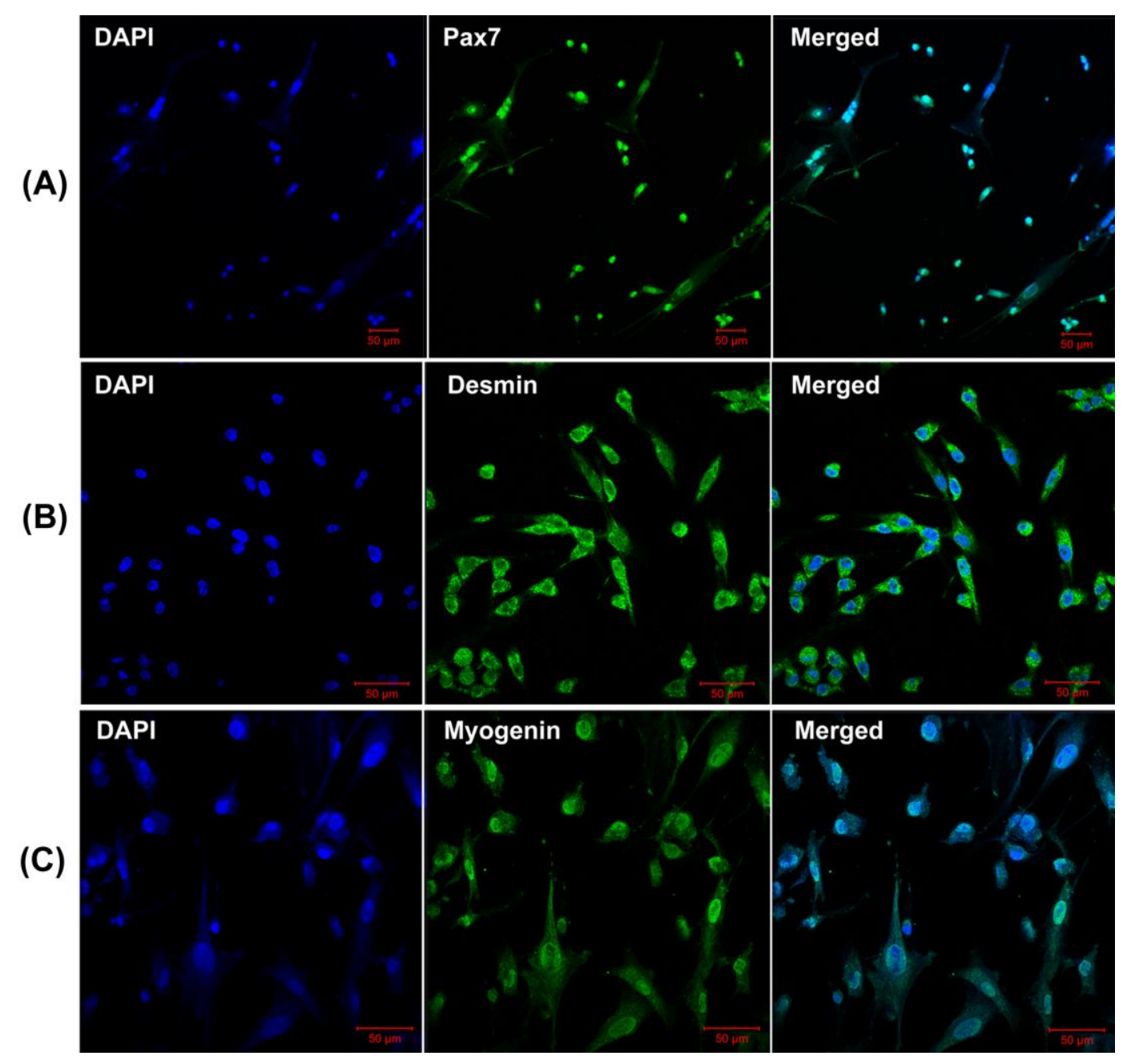

Figure 2. Characterization of porcine positive skeletal muscle satellite cells. (A) Immunofluorescence analysis of Pax7 expression on proliferating porcine skeletal muscle satellite cells. (B) Immunofluorescence analysis of Desmin expression on proliferating porcine skeletal muscle satellite cells. (C) Immunofluorescence analysis of myogenin expression on differentiated porcine skeletal muscle satellite cells. Bar $=50 \mu \mathrm{m}$. 


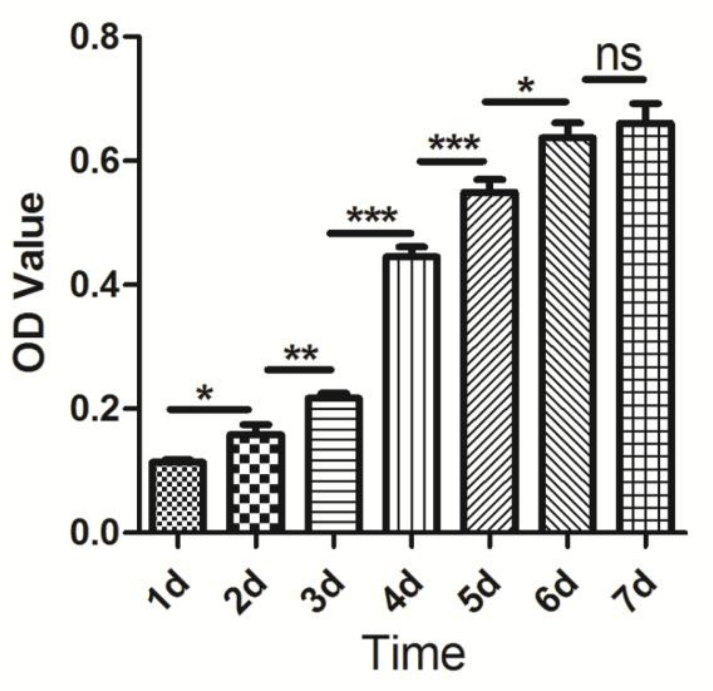

Figure 3. Proliferation assessment of porcine skeletal muscle satellite cells. CCK- 8 analysis for porcine skeletal muscle satellite cells proliferation at days $1,2,3,4,5,6$ and 7 . A p value of $<0.05$ is shown as $*, \mathrm{p}<0.01$ is shown as $* *$, and $\mathrm{p}<0.001$ is shown as $* * *$. No significance is shown as ns.

muscles, although we did not provide the evidence indicate which one is better. The phenotype of proliferating and differentiated porcine skeletal muscle satellite cells were shown in Figure 1.

At present, although several proteins have been demonstrated to characterize skeletal muscle satellite cells, including Pax7, M-cadherin, Cxcr4, syndecan3/4, and c-met (Fukada et al., 2013), Pax7 is the most commonly used molecular marker used to characterize the skeletal muscle satellite cells derived from distinct species. In our study, Pax7 and Desmin antibodies were used to characterize the proliferating positive muscle satellite cells, while myogenin antibody was used to monitor the differentiation capability of muscle satellite cells using immunofluorescence. The characterized results from immunofluorescence were shown in Figure 2. Furthermore, the result of CCK-8 analysis indicated that the isolated skeletal muscle satellite cells display normal proliferative capacity (Figure 3). Taken together, these results indicate that the optimized method can obtain high pure skeletal muscle satellite cells which can be utilized as cell model to investigate the molecular mechanisms of skeletal muscle growth and development.

\section{ACKNOWLEDGMENTS}

This work has been supported by Natural Science Foundation of Jiangsu Province (BK20130693 and BK20140688), Youth Science and Technology Innovation Fund of Nanjing Agricultural College (KJ2013020) and grants from the 973 Program (2014CB138502).

\section{REFERENCES}

Bennett, V. D., E. Cowles, H. D. Husic, and C. H. Suelter. 1986. Muscle cell cultures from chicken breast muscle have increased specific activities of creatine kinase when incubated at 41 degrees $\mathrm{C}$ compared with 37 degrees C. Exp. Cell Res. 164:63-70.

Bischoff, R. 1974. Enzymatic liberation of myogenic cells from adult rat muscle. Anat. Rec. 180:645-661.

Blanton, J. R., Jr., A. L. Grant, D. C. McFarland, J. P. Robinson, and C. A. Bidwell. 1999. Isolation of two populations of myoblasts from porcine skeletal muscle. Muscle Nerve. 22: 43-50.

Blau, H. M. and C. Webster. 1981. Isolation and characterization of human muscle cells. Proc. Natl. Acad. Sci. USA 78:56235627.

Bonavaud, S., O. Agbulut, G. D'Honneur, R. Nizard, V. Mouly, and G. Butler-Browne. 2002. Preparation of isolated human muscle fibers: A technical report. In Vitro Cell. Dev. Biol. -Anim. 38: 66-72.

Campion, D. R., R. L. Richardson, J. O. Reagan, and R. R. Kraeling. 1981. Changes in the satellite cell population during postnatal growth of pig skeletal muscle. J. Anim. Sci. 52: 1014-1018.

Di Foggia, V. and L. Robson. 2012. Isolation of satellite cells from single muscle fibers from young, aged, or dystrophic muscles. Methods Mol. Biol. 916: 3-14.

Dodson, M. V., E. L. Martin, M. A. Brannon, B. A. Mathison, and D. C. McFarland. 1987. Optimization of bovine satellite cellderived myotube formation in vitro. Tissue Cell 19:159-166.

Dodson, M. V., D. C. McFarland, E. L. Martin, and M. A. Brannon. 1986. Isolation of satellite cells from ovine skeletal muscles. J. Tissue Cult. Methods 10:233-237.

Doumit, M. E. and R. A. Merkel. 1992. Conditions for isolation and culture of porcine myogenic satellite cells. Tissue Cell 24: 253-262.

Fukada, S., Y. Ma, T. Ohtani, Y. Watanabe, S. Murakami, and M. Yamaguchi. 2013. Isolation, characterization, and molecular regulation of muscle stem cells. Front. Physiol. 4:317.

Kastner, S., M. C. Elias, A. J. Rivera, and Z. Yablonka-Reuveni. 2000. Gene expression patterns of the fibroblast growth factors and their receptors during myogenesis of rat satellite cells. J. Histochem. Cytochem. 48:1079-1096.

Mau, M., N. Oksbjerg, and C. Rehfeldt. 2008. Establishment and conditions for growth and differentiation of a myoblast cell line derived from the semimembranosus muscle of newborn piglets. In Vitro Cell. Dev. Biol. - Anim. 44:1-5.

Mauro, A. 1961. Satellite cell of skeletal muscle fibers. J. Biophys. Biochem. Cytol. 9:493-495.

Mesires, N. T. and M. E. Doumit. 2002. Satellite cell proliferation and differentiation during postnatal growth of porcine skeletal muscle. Am. J. Physiol. Cell. Physiol. 282:C899-906.

Rhoads, R. P., M. E. Fernyhough, X. Liu, D. C. McFarland, S. G. Velleman, G. J. Hausman, and M. V. Dodson. 2009. Extrinsic regulation of domestic animal-derived myogenic satellite cells II. Domest. Anim. Endocrinol. 36:111-126.

Rosenblatt, J. D., A. I. Lunt, D. J. Parry, and T. A. Partridge. 1995. Culturing satellite cells from living single muscle fiber explants. In Vitro Cell. Dev. Biol.-Anim. 31:773-779. 
Shefer, G. and Z. Yablonka-Reuveni. 2005. Isolation and culture of skeletal muscle myofibers as a means to analyze satellite cells. Methods. Mol. Biol. 290:281-304.

Theil, P. K., I. L. Sorensen, P. M. Nissen, and N. Oksbjerg. 2006. Temporal expression of growth factor genes of primary porcine satellite cells during myogenesis. Anim. Sci. J. 77: 330-337.
Wilschut, K. J., H. P. Haagsman, and B. A. J. Roelen. 2010. Extracellular matrix components direct porcine muscle stem cell behavior. Exp. Cell Res. 316:341-352.

Wilschut, K. J., S. Jaksani, J. Van Den Dolder, H. P. Haagsman, and B. A. J. Roelen. 2008. Isolation and characterization of porcine adult muscle-derived progenitor cells. J. Cell. Biochem. 105:1228-1239. 